\title{
Personnel Expenses and Productivity Change in Peruvian Stock Mining Companies
}

\author{
Johan Axcel Torres Bonilla ${ }^{1}$, Fiorella Melissa Arena Pariona Marcos ${ }^{1}$, Pedro Bernabe Venegas Rodriguez ${ }^{1}$, Nivardo \\ Alonzo Santillán Zapata ${ }^{1} \&$ Jimmy Alberth Deza Quispe ${ }^{1}$ \\ ${ }^{1}$ Universidad Continental, Peru \\ Correspondence: Johan Axcel Torres Bonilla, Universidad Continental, Peru. E-mail: 71290101@ continental.edu.pe
}

Received: November 4, 2020

Accepted: December 24, $2020 \quad$ Online Published: January 20, 2021

doi:10.5430/ijfr.v12n3p181

URL: https://doi.org/10.5430/ijfr.v12n3p181

\begin{abstract}
Copper mining activities have a huge importance for both the Peruvian economy and the world. Then, it is important to analyze how mining companies face productivity to stay afloat in the competitive world market. For this reason, Peruvian mining companies were analyzed in the 2016-2019 period by employing the Malmquist index as well as its decomposition. Two-year, three-year, and four-year intervals were used for a better understanding of the results. It was found that the major determinants for productivity change was technical efficiency change and technological switch.
\end{abstract}

Keywords: Malmquist index, copper mining companies, technical efficiency change, technological change

\section{Introduction}

Cooper was probably the first metal ever used by humankind. Since 8000 B.C. cooper was employed in coins and ornaments (Doebrich, 2009). Nowadays, cooper is harnessed in building construction, industrial machinery, vehicles and electronic devices (Doebrich, 2009). Copper is a good electrical conductor; then, plenty of electronic devices employ cooper pieces because of its transmission properties (Del Águila et al., 2017). In consequence, a huge demand for cooper have been increasing over the years (International Council on Mining and Metals, 2011).

A cooper global supply chain was established indeed (PwC, 2019). For one side, cooper manufacturing countries and on the other side nations blessed with cooper reserves. In the first class is located countries such as the United States, India and China which demands the major part of global cooper supply (Doebrich, 2009). Here China consumes and demand more than $50 \%$ of the cooper world supply (Bing et al., 2019). In the other group, Peru and Chile are the major cooper suppliers to the world (Fundación Chile, 2018).

Therefore, an interdependence relationship has been made in among these countries (Chan, 2019). Just focusing in Peru, it can be seen that cooper by itself provides more than $27 \%$ of the total Peruvian trading value (Ministerio de Energia y Minas, 2019). Moreover, Peru thanks to its friendly foreign investment environment continue attracting investments for future cooper extraction projects (Ernst and Young, 2019). According to the Cámara de Comercio de Lima (2019)those projects are valuated in more than fifty two billions of dollars. Of course, investments in cooper extraction projects would not be possible without the huge Peruvian reserves which according to the Peruvian Ministerio de Energía y Minas (2018) is the third around the world.

The principal trade partner for Peruvian cooper is China, to this country about $60 \%$ of Peruvian total cooper production is destined (Ministerio de Energia y Minas, 2019). The free trading agreement signed between Peru and China boosted this relationship; hence China replaced the United States as the principal destiny of Peruvian exports, which includes copper (Chan, 2019).

It is necessary to add that the Peruvian economy is one of social market (Olivos, 2010). Then, the Peruvian government allows private investment both national and international but with controls which guarantees social justice (Rivadeneira, 2009). Then, Peruvian mining production relies on private mining companies without any government intervention. However, the Peruvian government asks for taxes and contributions to the local government along with certain conditions for the mining activity (Sociedad Nacional de Minería Petróleo y Energía, 2011). Therefore, mining companies should seek the way to keep their investment profitable.

One way to get higher levels of firm profitability is by stimulating firm productivity. For instance, Muminović and 
Barać (2015) revealed that increasing productivity affected profitability positively in the dairy processing industry of Croatia. Also, Margaretha and Supartika (2016) demonstrated that in the Indonesian stock market companies, there was a positive relationship between productivity and profitability.

Therefore, it is necessary to know how mining companies are managing productivity in the last years. Hence, the current paper main objective will be to discover the mining companies' productivity evolution through the 2015-2019 period.

\section{Literature Review}

\subsection{Previous Research}

Studies about productivity changes were carried previously. Ali \& Lafta (2020) aimed to measure the economic efficiency and total productivity change of agricultural companies in Iraq in the 2005-2017 period. DEA and Malmquist index were harnessed for the research purpose. Labor and capital were employed as inputs; whereas agricultural firm' production as output. The research encountered that capital would increase the productivity as well as the technological change. Hence, this study regarding to DEA points out the huge importance of technological change.

Zhu et al. (2020) explored the efficiency and productivity of Pakistan's banking industry from 2006 to 2017. DEA and Malmquist index techniques were employed. Then interest expense and non-interest expense were employed as inputs, while net interest income and non-interest income were harnessed as output variables. The research found that there was a productivity decline for all banks in average. However, it was found that when grouping banks by their origin, it was shown that the foreign banks increased their productivity in average, while the domestic banks suffered reductions on their productivity. Although, this study is focused on service companies, it is important to understand the usage of financial factors as inputs.

Yang \& Fang (2020) examined the green productivity of Chinese real estate companies from 2015 to 2018. Then, Malmquist index was employed. Chosen inputs were total assets, number of employees and number of patents. While, output variables were operating income, net income, green credit index and $\mathrm{CO} 2$ emission. The research encountered that firms' green productivity increased in average from 0.701 to in 2015 to 0.849 in 2018 . Finally, the authors claimed that technological progress was vital for productivity improvement. Therefore, this study also highlits the importance of thechnological progress for the productivity analysis.

Sharif et al. (2019) analyzed the productivity change and efficiency of Malaysian companies. The period studied lasted from 2007 to 2016. Data Envelopment Analysis [hereinafter DEA] was harnessed as well as Malmquist Index. Total volume, dividends per share, market capitalization, price to book ratio, financial leverage were employed as inputs; while return on assets, return on common equity, and price earnings ratio were the output variables. The study found that productivity gain was due to a positive shift in the technology frontier and technical efficiency.

Yonnedi \& Rahman Panjaitan (2019) searched the efficiency and productivity of Indonesian regional development banks from 2011 to 2016 employing DEA and Malmquist index. The research used three variable selection approaches: intermediation approach, operational approach, and asset approach. For intermediation approach, third party funds, interest expense, and non-interest operating expenses were employed as inputs; while loans provided, interest income and non-interest income were selected as outputs. In the operational approach, interest expense, and non-interest operating expenses were the input variables; meanwhile, interest income and non-interest income were the chosen outcomes. Finally, for asset approach, labor expenses, cost of funds and fixed asset expenses were choses as input variables; in contrast, loans provided, and investment placement were selected as output variables. The research found that highest productivity change took place in the asset approach supported by the increase of technical efficiency and technological change. In intermediation and operation approach the productivity increased because of technical efficiency change and scale efficiency swap. In consequence, along with technological change this study concluded that technical efficiency is necessary to understand productivity change.

Masri \& Asbu (2018) studied the productivity change of national health systems in the Eastern Mediterranean countries from 2003 to 2014. Hence, DEA and Malmquist index were employed. Total population, population proportion under 15 years, population proportion over 60, gross domestic product per capita, human development index, total health expenditure, general government general government health expenditure, out of pocket expenditure, and skilled health professional density were employed as input variables. Meanwhile, life expectancy and infant mortality were harnessed as desirable and undesirable outputs, respectively. The research found that productivity fell in all but five countries specially driven by technological issues.

Consequently, examination of productivity switch was performed in different contexts around the world. Most of 
them encountered that technological change is of high importance to understand productivity change; also, those studies shown that the usage of financial factors as inputs are feasible. However, productivity change analysis in mining or extractive sectors were not as much as desired. Also, no studies were found about Peruvian mining companies' productivity change. Then, the current paper aims to analyze the productivity switches in Peruvian copper mining companies by employing the Malmquist index in order to fill the encountered gap of analysis.

\subsection{Productivity Change}

To talk about Malmquist index is necessary to refer to DEA. DEA is a non-parametric approach that employs linear programming techniques to estimate efficiency of set of units or Decision Management Unit [hereinafter, $D M U$ ], which is its technical name (Avkiran, 2006). Farrel (1957) conceived DEA as an efficiency analysis tool; however, further research has made it possible to employ DEA as a productivity change tool by the Malmquist Index. This index was developed by Caves, Christiensen and Diewert in 1982, who improved former Malmquist's ratios distance function research published in 1953 (Aghayi et al., 2019). Also, they took concepts of Shephard's theoretical indexes distance functions (Mohammadi \& Ranaei, 2011). Next, Fare, Grosskopf, Lindgren, and Roos could decompose productivity index by employing Farrel's efficiency measures (Delfín \& Navarro, 2015). Consequently, the Malmquist index, specially its decomposition analysis, was linked with DEA.

Malmquist index is mainly known as the product of efficiency change [catch up] and technological progress change [frontier]. Hereinafter, this decomposition will be called as decomposition one. Forsund (2002) depicts Malmquist index as follows:

$$
M\left(x^{t}, y^{t}, x^{t+1}, y^{t+1}\right)=\frac{D^{t+1}\left(x^{t+1}, y^{t+1}\right)}{D^{t}\left(x^{t}, y^{t}\right)} \quad\left[\frac{D^{t}\left(x^{t+1}, y^{t+1}\right)}{D^{t+1}\left(x^{t+1}, y^{t+1}\right)} \frac{D^{t}\left(x^{t}, y^{t}\right)}{D^{t+1}\left(x^{t}, y^{t}\right)}\right]^{1 / 2}
$$

Where:

$d^{t}:$ t period distance

$d^{t+1}: t+1$ period distance

$x^{t}:$ t period input vector

$x^{t+1}: t+1$ period input vector

$y^{t}:$ t period output vector

$y^{t+1}: t+1$ period output vector

$\Delta C E$ : Technical efficiency change: $\frac{D^{t+1}\left(x^{t+1}, y^{t+1}\right)}{D^{t}\left(x^{t}, y^{t}\right)}$

$\Delta C T$ : Technological progress change: $\left[\frac{D^{t}\left(x^{t+1}, y^{t+1}\right)}{D^{t+1}\left(x^{t+1}, y^{t+1}\right)} \frac{D^{t}\left(x^{t}, y^{t}\right)}{D^{t+1}\left(x^{t}, y^{t}\right)}\right]^{1 / 2}$

The first component, i.e. technical efficiency change, estimates relative efficiency behavior from the first-period, $t$, to the following one, $t+1$. The second part, scilicet technological progress, is measured by the geometrical mean of the frontier change of $t$, and $t+1$ period (Vargas et al., 2016). Technical efficiency change, also called global efficiency change, is taken from Charnes, Cooper and Rhodes work (Charnes et al., 1978). They introduced it as an efficiency amount which evaluates the global efficiency of all units by comparing them with a $D M U$ of reference or references (Jaime, 2016). Because of its creators' technical efficiency change is also referred as CCR. The component technology change refers to how firms produce get their outcomes by employing their resources; hence, a better technology enables more production with the equal resources (Çalışkan, 2015).

When the Malmquist index product [hereinafter, $M_{o}$ ] is $>1$, it indicates productivity gain. Otherwise, $M_{o}<1$ means productivity loss. Finally, $M_{o}=1$ shows no productivity change (Mohammadi \& Ranaei, 2011). For all Malmquist components, the scores interpretation remain the same as written above.

Fare, Grosskopf, Norris and Zhang, years later, proposed another decomposition view of the Malmquist ratio. They included the concepts of pure efficiency change and efficiency scale change; while maintaining technological change (Zofio, 2007). Hereinafter, this decomposition will be called decomposition two. Then Malmquist index can also be decomposed as follows:

$$
M\left(x^{t}, y^{t}, x^{t+1}, y^{t+1}\right)=\frac{D_{B C C}^{t+1}\left(x^{t+1}, y^{t+1}\right)}{D_{B C C}^{t}\left(x^{t}, y^{t}\right)}\left(\frac{D_{C C R}^{t+1}\left(x^{t+1}, y^{t+1}\right)}{D_{B C C}^{t+1}\left(x^{t+1}, y^{t+1}\right)} \frac{D_{B C C}^{t}\left(x^{t}, y^{t}\right)}{D_{C C R}^{t}\left(x^{t}, y^{t}\right)}\right)\left[\frac{D_{C C R}^{t}\left(x^{t+1}, y^{t+1}\right)}{D_{C C R}^{t+1}\left(x^{t+1}, y^{t+1}\right)} \frac{D_{C C R}^{t}\left(x^{t}, y^{t}\right)}{D_{C C R}^{t+1}\left(x^{t}, y^{t}\right)}\right]^{1 / 2}
$$


Where:

$$
\begin{aligned}
& \Delta C P^{t ; t+1}: \text { Pure efficiency change: } \frac{D_{B C C}^{t+1}\left(x^{t+1}, y^{t+1}\right)}{D_{B C C}^{t}\left(x^{t}, y^{t}\right)} \\
& \Delta C S^{t ; t+1}: \text { Efficiency scale change: }\left(\frac{D_{C C R}^{t+1}\left(x^{t+1}, y^{t+1}\right)}{D_{B C C}^{t+1}\left(x^{t+1}, y^{t+1}\right)} \frac{D_{B C C}^{t}\left(x^{t}, y^{t}\right)}{D_{C C R}^{t}\left(x^{t}, y^{t}\right)}\right) \\
& \Delta C T^{t ; t+1}: \text { Technological progress change: }\left[\frac{D_{C C R}^{t}\left(x^{t+1}, y^{t+1}\right)}{D_{C C R}^{t+1}\left(x^{t+1}, y^{t+1}\right)} \frac{D_{C C R}^{t}\left(x^{t}, y^{t}\right)}{D_{C C R}^{t+1}\left(x^{t}, y^{t}\right)}\right]^{1 / 2}
\end{aligned}
$$

The pure efficiency change score is taken from Banker, Charnes and Cooper work (Banker et al., 1984). This efficiency score, also called $B C C$, takes into consideration $D M U$ magnitude; hence, $B C C$ compares a $D M U$ only with one of similar magnitude (Lai, 2013). Scale efficiency is the coefficient obtained by dividing the long term efficiency [i.e. $C C R$ ] and the short term one [i.e. $B C C$ ] (Banker et al., 1984). Scale efficiency determines if $D M U$ works in an optimal operation scale or in a shortened or oversized one (Bruno \& Erbetta, 2013).

Finally, Malmquist index can analyze the productivity changes in a set of intervals which ranks from two-year interval (Cooper et al., 2011).

\section{Methodology}

First, cooper mining companies were selected according to its data availability. Then, only mining companies that participate in the Peruvian stock market were choses since the Ley de Mercado de Valores (2011) obligate these firms to keep an open access policy regarding their financial statements. Hence, all data was collected from the SMV database. Analyzed companies are shown in Table 1.

Table 1. Companies analyzed

\begin{tabular}{lc}
\hline Company Name & Company short term \\
\hline Buenaventura & BUENAV \\
Santa Luisa & LUISA \\
Nexa Resources Peru & NEXAPE \\
Nexa Resources Atacocha & ATACOC \\
Cerro Verde & CVERDE \\
Corona & MINCOR \\
El Brocal & BROCAL \\
Southern Peru & SCCO \\
Volcan & VOLCA \\
\hline
\end{tabular}

It was necessary to follow Périco et al. (2017) methodological steps to get Malmquist index since as stated before it is linked to DEA efficiency analysis. First step of all, Périco et al. (2017) state that it is necessary to choose the variables necessary for the analysis; i.e. select output and inputs variables. Hence, the current research selected the elements of a cash flow financial statement [operating activities, investing activities and financing activities] as inputs, while sales as output. The reasons for choosing the parts of the cash flow statement was the homogeneity in the financial statements among the analyzed units; and, the accurate information about how resources are expended that only cash flow can give (Sherman, 2015).

It is also necessary to keep in mind the number of input and outputs as suggested by Sarkis in Avkiran (2006). According to Sarkis, the $D M U$ quantity can be; at least twice the sum of inputs and outputs, or at least three times the sum of inputs and outputs, or at least two times the product of inputs and outputs (Avkiran, 2006). Since the DMU quantity in the current analysis was nine, the number of inputs were three and there was only one input, the three options were fulfilled. Table 2 shows the variables chosen for the analysis. 
Table 2. Set of variables for the productivity analysis

\begin{tabular}{lc}
\hline Inputs & Outputs \\
\hline Operating activities & Sales \\
Investing activities & \\
Financing activities & \\
\hline
\end{tabular}

Table 3. Correlation test

\begin{tabular}{lllll}
\hline & Sales & $\begin{array}{l}\text { Operating } \\
\text { activities }\end{array}$ & $\begin{array}{l}\text { Investing } \\
\text { activities }\end{array}$ & $\begin{array}{l}\text { Financing } \\
\text { activities }\end{array}$ \\
\hline Sales & 1.0000 & & & \\
Operating activities & 0.7416 & 1.0000 & & \\
& $0.000^{* * *}$ & & & \\
Investing activities & 0.8272 & 0.7774 & 1.0000 & \\
& $0.000^{* * *}$ & $0.000^{* * *}$ & & \\
Financing activities & 0.6166 & 0.3478 & 0.3515 & 1.0000 \\
& $0.001 * * *$ & $0.038^{* *}$ & $0.036^{* *}$ & \\
\hline
\end{tabular}

After choosing the variables, Périco et al. (2017) recommend carrying a correlation test between the variables. Moreover, Avkiran (2006) claims that this analysis is to avoid redundant variables that may decrease the DEA discrimination power. Although Avkiran (2006) suggests that there is a risk of redundancy when correlation score is higher than .9, he remarks researcher criteria to establish the upper limit of correlation score and choose what variable is necessary to eliminate. Therefore, correlation test was performed for the whole period as shown in Table 3 . It was not necessary to eliminate any variable since there was not redundancy between the input variables.

Moreover, Périco et al. (2017) insists on choosing the model orientation [i.e. output or input orientation]. An input-oriented model seeks to minimize inputs at a given output level, and an output-oriented model aims to minimize outputs at a given input level (Aziz et al., 2013). Lai (2013) suggest that the research should study if it is more feasible in the real world to minimize inputs or maximize outputs. Then, it was assumed for the research that it is going to be more realistic to maximize outputs rather than minimizing inputs. Therefore, output orientation was chosen.

Although Périco et al. (2017) also suggest on choosing the suitable return to scale [constant return to scale or variable return to scale], it was not necessary since this research was focused on productivity analysis rather than efficiency study.

Furthermore, Alemán et al. (2003), Avkiran (2006), Charles et al. (2011) and Wang et al. (2016) suggest verifying the isotonicity assumption which can be described as the condition of no outputs reduction for inputs increasing (Wang, 2016). As shown in Table 2, all inputs had positive correlations to the output. Hence, it was proved that if inputs increase the output will grow.

After meeting all suggestions for building the productivity model, data was analyzed to Malmquist index scores employing the DEA solver by Springer software. For a better analysis it was taken two-year, three-year, and four-year intervals. 


\section{Results}

Table 4. Descriptive statistic

\begin{tabular}{|c|c|c|c|c|c|}
\hline \multirow[t]{2}{*}{ Variable } & \multirow[t]{2}{*}{ Measure } & \multicolumn{4}{|c|}{ Year } \\
\hline & & 2016 & 2017 & 2018 & 2019 \\
\hline \multirow[t]{4}{*}{ Sales* } & Mean & 651036 & 826552 & 821983 & 802480 \\
\hline & Max & 2384154 & 3202931 & 3054026 & 2940064 \\
\hline & Min & 46017 & 92989 & 85370 & 69343 \\
\hline & Coefficient of variation & 1.2331 & 1.2674 & 1.3041 & 1.3991 \\
\hline \multirow{4}{*}{$\begin{array}{l}\text { Operating } \\
\text { activities* }\end{array}$} & Mean & 239246 & 265024 & 240612 & 250811 \\
\hline & $\operatorname{Max}$ & 951565 & 776984 & 654249 & 719416 \\
\hline & Min & 7766 & 5617 & 32099 & 8498 \\
\hline & Coefficient of variation & 1.2142 & 1.0191 & 0.9784 & 0.9631 \\
\hline \multirow{4}{*}{$\begin{array}{l}\text { Investing } \\
\text { activities* }\end{array}$} & Mean & 177843 & 149297 & 195592 & 173906 \\
\hline & Max & 683554 & 756933 & 920812 & 665015 \\
\hline & Min & 1091 & 5042 & 5393 & 11646 \\
\hline & Coefficient of variation & 1.3837 & 1.5770 & 1.5319 & 1.3499 \\
\hline \multirow{4}{*}{$\begin{array}{l}\text { Financing } \\
\text { activities* }\end{array}$} & Mean & 157108 & 204437 & 106997 & 175600 \\
\hline & $\operatorname{Max}$ & 793169 & 971593 & 450000 & 386435 \\
\hline & Min & 0.0000 & 0.0000 & 0.0000 & 371 \\
\hline & Coefficient of variation & 1.6518 & 1.4813 & 1.4691 & 0.8634 \\
\hline
\end{tabular}

*expressed in thousands of US\$

Table 5. Two-year interval Malmquist Index

\begin{tabular}{|c|c|c|c|c|c|c|c|c|c|c|c|c|c|c|c|}
\hline \multirow[t]{2}{*}{ DMU } & \multicolumn{3}{|c|}{ Malmquist Index } & \multicolumn{3}{|c|}{ Technical efficiency change } & \multicolumn{3}{|c|}{ Pure efficiency change } & \multicolumn{3}{|c|}{ Technological change } & \multicolumn{3}{|c|}{ Scale efficiency } \\
\hline & $\begin{array}{l}2016 \\
\Rightarrow>2017\end{array}$ & $\begin{array}{l}2017 \\
=>2018\end{array}$ & $\begin{array}{l}2018 \\
=>2019\end{array}$ & $\begin{array}{l}2016 \\
\Rightarrow 2017\end{array}$ & $\begin{array}{l}2017 \\
\Rightarrow>2018\end{array}$ & $\begin{array}{l}2018 \\
\Rightarrow>2019\end{array}$ & $\begin{array}{l}2016 \\
\Rightarrow>2017\end{array}$ & $\begin{array}{l}2017 \\
\Rightarrow>2018\end{array}$ & $\begin{array}{l}2018 \\
\Rightarrow>2019\end{array}$ & $\begin{array}{l}2016 \\
\Rightarrow>2017\end{array}$ & $\begin{array}{l}2017 \\
=>2018\end{array}$ & $\begin{array}{l}2018 \\
=>2019\end{array}$ & $\begin{array}{l}2016 \\
\Rightarrow>2017\end{array}$ & $\begin{array}{l}2017 \\
=>2018\end{array}$ & $\begin{array}{l}2018 \\
\Rightarrow>2019\end{array}$ \\
\hline LUISA & 0.6225 & 0.7684 & 0.3983 & 0.9617 & 1.0398 & 0.6049 & 1.0000 & 1.0000 & 0.9996 & 0.6472 & 0.7390 & 0.6584 & 0.9617 & 1.0398 & 0.6051 \\
\hline NEXAPE & 2.9690 & 0.4327 & 0.4831 & 2.0562 & 1.0000 & 0.6871 & 1.0000 & 1.0000 & 0.9607 & 1.4439 & 0.4327 & 0.7030 & 2.0562 & 1.0000 & 0.7152 \\
\hline ATACOC & 1.0000 & 1.0000 & 1.6271 & 1.0000 & 1.0000 & 1.0000 & 1.0000 & 1.0000 & 1.0000 & 1.0000 & 1.0000 & 1.6271 & 1.0000 & 1.0000 & 1.0000 \\
\hline CVERDE & 1.5733 & 0.5994 & 1.0663 & 1.0537 & 1.2512 & 1.0062 & 1.0000 & 1.0000 & 1.0000 & 1.4932 & 0.4790 & 1.0598 & 1.0537 & 1.2512 & 1.0062 \\
\hline MINCOR & 0.9320 & 0.7553 & 1.6634 & 0.6675 & 1.8275 & 1.2928 & 0.7564 & 1.6372 & 1.0000 & 1.3962 & 0.4133 & 1.2866 & 0.8825 & 1.1162 & 1.2928 \\
\hline BROCAL & 1.0285 & 2.2306 & 0.8688 & 0.9919 & 2.9667 & 1.2923 & 1.0165 & 1.0077 & 1.2813 & 1.0369 & 0.7519 & 0.6723 & 0.9758 & 2.9440 & 1.0086 \\
\hline SCCO & 1.3175 & 1.1486 & 0.7216 & 0.9112 & 5.7978 & 0.5084 & 1.0000 & 1.0000 & 1.0000 & 1.4459 & 0.1981 & 1.4193 & 0.9112 & 5.7978 & 0.5084 \\
\hline VOLCA & 0.8215 & 0.9786 & 0.8326 & 0.6979 & 2.0191 & 0.5018 & 0.5119 & 1.0794 & 0.8031 & 1.1770 & 0.4846 & 1.6593 & 1.3634 & 1.8706 & 0.6248 \\
\hline$\%$ growth & 55.56 & 33.33 & 33.33 & 22.22 & 77.78 & 44.44 & 55.56 & 66.67 & 33.33 & 77.78 & 0.00 & 55.56 & 33.33 & 77.78 & 44.44 \\
\hline$\%$ decreasing & 33.33 & 55.56 & 66.67 & 66.67 & 0.00 & 44.44 & 33.33 & 11.11 & 55.56 & 11.11 & 88.89 & 44.44 & 55.56 & 0.00 & 44.44 \\
\hline Mean & 1.2793 & 1.1055 & 0.9287 & 1.0352 & 2.1809 & 0.8812 & 0.9436 & 1.1189 & 1.0043 & 1.2133 & 0.5828 & 1.0842 & 1.1126 & 2.0050 & 0.8672 \\
\hline Max & 2.9690 & 2.2306 & 1.6634 & 2.0562 & 5.7978 & 1.2928 & 1.2076 & 1.6372 & 1.2813 & 1.4932 & 1.0000 & 1.6593 & 2.0562 & 5.7978 & 1.2928 \\
\hline Min & 0.6225 & 0.4327 & 0.3983 & 0.6675 & 1.0000 & 0.5018 & 0.5119 & 1.0000 & 0.8031 & 0.6472 & 0.1981 & 0.6584 & 0.8087 & 1.0000 & 0.5084 \\
\hline $\begin{array}{l}\text { Coefficient of } \\
\text { variation }\end{array}$ & 0.5420 & 0.5636 & 0.4869 & 0.3922 & 0.7086 & 0.3565 & 0.2094 & 0.2010 & 0.1216 & 0.2298 & 0.4175 & 0.3921 & 0.3476 & 0.7806 & 0.3020 \\
\hline
\end{tabular}


Table 6. Three-year interval Malmquist Index

\begin{tabular}{|c|c|c|c|c|c|c|c|c|c|c|}
\hline \multirow[t]{2}{*}{ DMU } & \multicolumn{2}{|c|}{ Malmquist Index } & \multicolumn{2}{|c|}{ Technical efficiency change } & \multicolumn{2}{|c|}{ Pure efficiency change } & \multicolumn{2}{|c|}{ Technological change } & \multicolumn{2}{|l|}{ Scale efficiency } \\
\hline & $2016=>2018$ & $2017=>2019$ & $2016=>2018$ & $2017=>2019$ & $2016=>2018$ & $2017=>2019$ & $2016=>2018$ & $2017=>2019$ & $2016=>2017$ & $2017=>2018$ \\
\hline BUENAV & 1.6236 & 1.4149 & 2.6620 & 2.8282 & 1.6248 & 1.3373 & 0.6099 & 0.5003 & 1.6383 & 2.1149 \\
\hline LUISA & 0.4592 & 0.3050 & 1.0000 & 0.6290 & 1.0000 & 0.9996 & 0.4592 & 0.4849 & 1.0000 & 0.6292 \\
\hline NEXAPE & 1.5802 & 0.1912 & 2.0562 & 0.6871 & 1.0000 & 0.9607 & 0.7685 & 0.2783 & 2.0562 & 0.7152 \\
\hline ATACOC & 1.0000 & 0.7518 & 1.0000 & 1.0000 & 1.0000 & 1.0000 & 1.0000 & 0.7518 & 1.0000 & 1.0000 \\
\hline CVERDE & 0.8117 & 0.5927 & 1.3184 & 1.2589 & 1.0000 & 1.0000 & 0.6157 & 0.4708 & 1.3184 & 1.2589 \\
\hline MINCOR & 0.6698 & 1.1810 & 1.2199 & 2.3625 & 1.2384 & 1.6373 & 0.5491 & 0.4999 & 0.9850 & 1.4430 \\
\hline BROCAL & 1.8459 & 1.7790 & 2.9427 & 3.8338 & 1.0244 & 1.2911 & 0.6273 & 0.4640 & 2.8727 & 2.9693 \\
\hline SCCO & 1.7099 & 1.1410 & 5.2829 & 2.9474 & 1.0000 & 1.0000 & 0.3237 & 0.3871 & 5.2829 & 2.9474 \\
\hline VOLCA & 0.9068 & 0.5207 & 1.4092 & 1.0131 & 0.5525 & 0.8669 & 0.6435 & 0.5140 & 2.5505 & 1.1687 \\
\hline$\%$ growth & 44.4400 & 44.4400 & 77.7800 & 66.6700 & 55.5600 & 55.5600 & 0.0000 & 0.0000 & 66.6700 & 66.6700 \\
\hline$\%$ constant & 11.1100 & 0.0000 & 22.2200 & 11.1100 & 22.2200 & 11.1100 & 11.1100 & 0.0000 & 22.2200 & 11.1100 \\
\hline$\%$ decreasing & 44.4400 & 55.5600 & 0.0000 & 22.2200 & 22.2200 & 33.3300 & 88.8900 & 100.0000 & 11.1100 & 22.2200 \\
\hline Mean & 1.1786 & 0.8753 & 2.0990 & 1.8400 & 1.0489 & 1.1214 & 0.6219 & 0.4835 & 2.0782 & 1.5830 \\
\hline Max & 1.8459 & 1.7790 & 5.2829 & 3.8338 & 1.6248 & 1.6373 & 1.0000 & 0.7518 & 5.2829 & 2.9693 \\
\hline Min & 0.4592 & 0.1912 & 1.0000 & 0.6290 & 0.5525 & 0.8669 & 0.3237 & 0.2783 & 0.9850 & 0.6292 \\
\hline $\begin{array}{l}\text { Coefficient of } \\
\text { variation }\end{array}$ & 0.4351 & 0.6107 & 0.6619 & 0.6365 & 0.2668 & 0.2210 & 0.3040 & 0.2590 & 0.6680 & 0.5635 \\
\hline
\end{tabular}

Table 4 depicts the descriptive statistics of the employed data. It can be observed that average sales increased continuously from 2016 to 2019 as well as its dispersion. Sales maximum number also increased from 2016 to 2019 but it was not constant as well as the minimum sale levels.

Although mean operating activities had an unstable behavior since a growing year was immediately followed by a decreasing one, it was higher in 2019 than 2016. The upper limit of operating activities decreased from 2016 to 2019 as its lower bound. Nonetheless, its variation decreased from 2016 to 2019.

Average investing activities average also had a fluctuant evolution, with the 2019 value lower than its initial number. Similarly, its maximum values and coefficient of variation also were lower in the final year. Only investing activities lower bound was higher in 2019 than 2016.

Finally, financing activities 2019 average value was lower than its 2016 mean value. Moreover, its maximum number also decreased as its coefficient of variation. However, in 2019 it could increase its lower bound from zero to 371 thousand of US\$.

Table 5 shows the two-year Malmquist index as well as its decomposition. In such table it is seen that in the first period, $55.56 \%$ of companies grew its productivity, while $33.33 \%$ decreased it. The maximum productivity increase was done by NEXAPE, while the lowest score was reached by LUISA. In the second period, $33.33 \%$ of firms could increase its Malmquist index, while 55.56\% of companies had reductions of its productivity. In this opportunity, BROCAL had the highest positive productivity change; meanwhile, NEXAPE had the lowest performance. In the final period, the percentage of both growing and decreasing productivity firms was the same as the second period. However, in this period MINCOR had the best productivity performance, and LUISA had the worst productivity switch again.

In the technical efficiency change in the period first period the highest values were obtained by NEXAPE. In the second and third period SCCO and MINCOR, respectively. The lowest values were got by MINCOR, ATACOC and VOLCA. From the initial to the final period, more companies could improve its technical efficiency variation.

The highest score in the pure efficiency change 2016-2017 period was reached by BUENAV, in the next period it was met by MINCOR, and in the final stretch it was gained by BROCAL. On the other hand, VOLCA got the lowest 
results in the terms 2016-2017 and 2018-2019; while, in the 2017-2018 stretch the lowest value belonged to CVERDE but it was not a reduction value. From the initial term to the last one less firm were able to improve its pure efficiency.

CVERDE, ATACOC and VOLCA reached the highest technological swap values. It is important to add that the highest value in the period 2017-2018 was not a one-off increasing but a constant one. On the other hand, LUISA had highest decreasing scores in both first and last period; in the 2017-2018 stretch the lowest value was met by SCCO. Like pure efficiency change, from the initial to the final term there was a reduction of improving firms in technological switch.

About the scale efficiency change, it is shown that NEXAPE, SCCO and MINCOR had the highest values in the terms 2016-2017, 2017-2018 and 2018-2019 respectively. Meanwhile BUENAV, NEXAPE and SCCO had the lowest ones in the periods described above. From the initial period to the final one more enterprise could increase its scale efficiency.

Table 6 portrays the Malmquist index change and its decomposition in three-year interval. In such table is seen that in the Malmquist Index BROCAL had the highest scores, while LUISA and NEXAPE were the worst performing firms. When comparing the two periods it is observed that there was a growth in the number of companies with reductions in their productivity, the percentage of companies that improve their productivity remained the same; and there was an increment in companies that decreased their productivity.

In the technical efficiency change, it is seen that SCCO and BROCAL had the highest scores. On the other hand, in the initial period the lowest score was reached by ATACOC, though it was a constant score, and in the final period LUISA had the poorest performance. Plenty of companies increased their technical efficiency in both terms.

In the pure efficiency change, VOLCA had the lowest scores in both terms, while BUENAV and MINCOR were the best performing companies. In the technological change part, ATACOC performed the best in the two periods, while SCCO and NEXAPE reached the lowest values. In the two terms there was not any growing company. Finally, in the scale efficiency element, it is observed that MINCOR and LUISA obtained the worst scores; while SCCO and BROCAL the best ones.

Table 7. Four-year interval Malmquist index

\begin{tabular}{lccrrr}
\hline DMU & $\begin{array}{l}\text { Malmquist } \\
\text { Index }\end{array}$ & $\begin{array}{l}\text { Technical } \\
\text { efficiency change }\end{array}$ & \multicolumn{1}{l}{$\begin{array}{l}\text { Pure efficiency } \\
\text { change }\end{array}$} & $\begin{array}{l}\text { Technological } \\
\text { change }\end{array}$ & Scale efficiency \\
\cline { 2 - 6 } & $2016=>2019$ & $2016=>2019$ & $2016=>2019$ & $2016=>2019$ & $2016=>2017$ \\
\hline BUENAV & 1.7026 & 2.7620 & 1.6149 & 0.6164 & 1.7104 \\
LUISA & 0.2223 & 0.6049 & 0.9996 & 0.3675 & 0.6051 \\
NEXAPE & 0.9233 & 1.4129 & 0.9607 & 0.6535 & 1.4707 \\
ATACOC & 0.9502 & 1.0000 & 1.0000 & 0.9502 & 1.0000 \\
CVERDE & 0.9968 & 1.3265 & 1.0000 & 0.7514 & 1.3265 \\
MINCOR & 1.0431 & 1.5771 & 1.2384 & 0.6614 & 1.2735 \\
BROCAL & 1.5256 & 3.8027 & 1.3125 & 0.4012 & 2.8974 \\
SCCO & 1.6748 & 2.6857 & 1.0000 & 0.6236 & 2.6857 \\
VOLCA & 0.4792 & 0.7071 & 0.4437 & 0.6778 & 1.5935 \\
\% growth & 44.4400 & 66.6700 & 55.5600 & 0.0000 & 77.7800 \\
$\%$ constant & 0.0000 & 11.1100 & 11.1100 & 0.0000 & 11.1100 \\
$\%$ decreasing & 55.5600 & 22.2200 & 33.3300 & 100.0000 & 11.1100 \\
Mean & 1.0575 & 1.7643 & 1.0633 & 0.6337 & 1.6181 \\
Max & 1.7026 & 3.8027 & 1.6149 & 0.9502 & 2.8974 \\
Min & 0.2223 & 0.6049 & 0.4437 & 0.3675 & 0.6051 \\
Coefficient of & 0.4824 & 0.6142 & 0.2988 & 0.2748 & 0.4593 \\
variation & & & & & \\
\hline
\end{tabular}


Table 7 exhibits the Malmquist index and its components in the four-year interval which is the longest one. According to the Malmquist index, BUENAV performed the best, while LUISA the worst. It is interesting to add that LUISA had the poorest performing also in technical efficiency swap, technological change, and scale efficiency. Furthermore, $55.56 \%$ of companies suffered contractions on their productivity but no one remained equal. In the technical efficiency switch component BROCAL had the highest score. Moreover, $66.67 \%$ of companies could improve its technical efficiency, but $22.22 \%$ suffered reductions in this element.

BUENAV also performed the best in the pure efficiency change element, while VOLCA had the lowest score. About $56 \%$ of firms could improve in this element, while $11.11 \%$ did not have any changes. ATACOC had the highest technological switch among the set of companies analyzed. However, no company could improve its technology in the interval. The last component, scale efficiency, shows that BROCAL had the best score. Also, in this element $77.78 \%$ of firms could increase their scores while $11.11 \%$ could not.

It is seen that the major enhancer for the switch in productivity is technical efficiency change when decomposition one is done. Otherwise, when decomposition two is performed, the most relevant parts are technological change followed by scale efficiency. Hence it is not surprising that companies such as NEXAPE and MINCOR had the highest scores in Malmquist index, Technical efficiency change, and scale efficiency in the periods 2016-2017 and 2018-2019 respectively. Moreover, LUISA had the worst productivity swap and the lowest scores in technical efficiency change, technological change, and scale efficiency change in the four-year interval.

\section{Discussion}

The current paper analyzed the productivity changes of Peruvian mining companies in the 2016-2019 period. Malmquist index analysis was employed in two-year, three-year, and four-year intervals. It was seen that according to the period analyzed not all companies could maintain its growing productivity level; then there were changes across the time. For instance, in the two-year interval analysis NEXAPE had the highest score in the first period but the lowest in the second one.

When comparing the intervals, it is seen that the companies that did well in one interval not necessarily had good outcomes in the other ones. For example, CVERDE had a growing score in the two-year interval first period but a decreasing one in the first period of the three-year interval. Moreover, BUENAV did not have the highest score in any period of the two-year analysis but it was the best performing firm in the four-year interval.

It was also observed that the major determinant for the Productivity change or Malmquist index was technical efficiency in the first decomposition. This finding matches with the results of Zhu et al. (2020), Sharif et al. (2019), and Yonnedi \& Rahman Panjaitan (2019) since they encountered that technical efficiency was determinant for a company to get its productivity index in their analysis of banking industry, Malaysian companies, and regional banking respectively.

If the Malmquist index is decomposed by employing the decomposition two, it was found that technology swap was the major driver for the Productivity index. Then, this finding matches with the results of Ali \& Lafta (2020), Sharif et al. (2019), Yi et al. (2019), and Masri \& Asbu (2018) studies. Ali \& Lafta (2020) in their analysis about agricultural companies, Yi et al. (2019) study about real estate companies, Masri \& Asbu (2018) in their study on national health systems, and as well as Sharif et al. (2019) encountered that technological change was a major determinant for Productivity outcome.

Finally, it was seen that also Scale efficiency was an important factor for Productivity Index as the research made by Yonnedi \& Rahman Panjaitan (2019) in the Indonesian regional banks.

\section{Conclusions}

The current research aimed to study the productivity evolution of Peruvian mining companies in the period 2016-2019. Hence, it was necessary to employ the Malmquist index as well as its components. Moreover, the productivity analysis was performed in two-year, three-year, and four-year intervals for a better perspective. According to the intervals some companies did well in certain periods but not in other. Also, there were companies with discrete performance in certain intervals but with outstanding performance in other. The research also found that technical efficiency followed by technological change and scale efficiency had the major impacts on the Productivity switch.

Therefore, it is important for companies to keep the pace and not allow reductions in their productivity since both productivity and profitability are related. It can be stated that for copper mining companies is important to maintain and improve at least its technical efficiency as well its technological improvement. Better processes with an optimal 
use of resources may lead a better performance in this way.

Moreover, it is worrying that each year less companies had increments on their productivity; however, it is important to understand that mining activities have a high dependence on factors outside the country, such as the international prices and demand, since almost the whole mining production is exported overseas. Then, for avoiding reduction on productivity it is important for companies to be flexible to the continuous changing environments of the world. Hence, prevision and quick actions are important for companies to be one step further than the changes. Although not all scenarios can be predicted, it is necessary for firms to be flexible and quickly adaptive for the unexpected.

Finally, it is desirable to include in future studies data about employees' number, machines and other physical factors that could also explain the productivity change. Also, it would be recommendable to include non-stock firms since data about those firms are desirable but difficult to get.

\section{References}

Aghayi, N., Tavana, M., \& Maleki, B. (2019). A Malmquist Productivity Index with Directional Distance Function and Uncertain Data. Scientia Iranica, 26(6), 3819-3834. https://doi.org/10.24200/sci.2018.5259.1173

Alemán, P., Orlando, Y., Quijano, A., Ricardo, D., Freddy, J., Análisis, D. E. L., \& Datos, E. D. E. (2003). La eficiencia relativa en los colegios distritales de Bogotá: Una aplicación del análisis envolvente de datos. Cuadernos de Administración, 16(26), 35-60.

Ali, E. H., \& Lafta, A. H. (2020). Measuring the economic efficiency and total productivity of resource and the technical change of agricultural companies in Iraq using SFA and DEA for the period 2005-2017. Iraqi Journal of Agricultural Sciences, 51(4), 1104-1117. https://doi.org/10.36103/ijas.v51i4.1089

Avkiran, N. (2006). Productivity Analysis in the Service Sector with Data Envelopment Analysis (Second). N K Avkiran. https://doi.org/10.1002/9781118644898.ch10

Aziz, N. A. A., Janor, R. M., \& Mahadi, R. (2013). Comparative Departmental Efficiency Analysis within a University: A DEA Approach. Procedia - Social and Behavioral Sciences, 90, 540-548. https://doi.org/10.1016/j.sbspro.2013.07.124

Banker, R., Charnes, A., \& Cooper, W. (1984). Some models for estimating technical and scale inefficiencies in data envelopment analysis. Management Science, 30(9), 1078-1092.

Bing, X., Roth, M., \& Santabárbara, D. (2019). Impacto global de una desaceleración en China. Artículos Analíticos. Boletín Económico 4/2019.

Bruno, C., \& Erbetta, F. (2013). Benchmarking Regulators: a data envelopment analysis of Italian water authorities. In Handbook of Research on Strategic Performance Management and Measurement Using Data Envelopment Analysis (pp. 388-406). https://doi.org/10.4018/978-1-4666-4474-8

Çalı̧̧kan, H. K. (2015). Technological Change and Economic Growth. Procedia - Social and Behavioral Sciences, 195, 649-654. https://doi.org/10.1016/j.sbspro.2015.06.174

Cámara de Comercio de Lima. (2019). Informe ecoómico. La Cámara, 7-8.

Chan, J. (2019). Los nueve años del TLC Perú - China. Su negociación y sus resultados. Agenda Internacional, 26(37), 89-117. https://doi.org/10.18800/agenda.201901.003

Charles, V., Kumar, M., Zegarra, L. F., \& Avolio, B. (2011). Benchmarking Peruvian Banks using Data Envelopment Analysis. Journal of CENTRUM Cathedra: The Business and Economics Research Journal, 4(2), 147-164. https://doi.org/10.7835/jcc-berj-2011-0055

Charnes, A., Cooper, W. W., \& Rhodes, E. (1978). Measuring the efficiency of decision making units. European Journal of Operational Research, 2(6), 429-444. Retrieved from https://econpapers.repec.org/RePEc:eee:ejores:v:2:y:1978:i:6:p:429-444

Cooper, W., Seiford, L., \& Zhu, J. (2011). Handbook on Data Envelopment Analysis (First, Issues 978-1-4419-6151-8). Springer. https://doi.org/10.1007/978-1-4419-6151-8

Del Águila, P., Martínez, M., \& Regalado, F. (2017). COBRE: Evolución reciente y POTENCIAL DE DESARROLLO. Moneda, 171, 29-32. http://www.bcrp.gob.pe/docs/Publicaciones/Revista-Moneda/moneda-171/moneda-171.pdf

Delfín, O., \& Navarro, J. (2015). Productividad total de los factores en las terminales de contenedores en los puertos de México: Una medición a través del índice Malmquist. Contaduria y Administracion, 60(3), 663-685. 
https://doi.org/10.1016/j.cya.2015.05.011

Doebrich, J. (2009, May). Copper - A Metal for the Ages How Do We Use Copper? Where Does Copper Come From?. USGS Science for a Changing World, 1-4. Retrieved from http://pubs.usgs.gov/fs/2009/3031/

Ennst and Young. (2019). Peru's mining \& metals investment guide 2019/2020. Retrieved from http://www.embajadadelperu.org.co/docs/Mining 2019 - 2020.pdf

Farrel, M. (1957). The measurament of productive efficiency. Journal of the Royal Statiscal Society, 120(3), 253-257.

Fundación Chile. (2018). Fuerza Laboral Minería del Perú 2018.

International Council on Mining and Metals. (2011). Sustainable Development and the Global Copper Supply Chain: International Research Team Report. June, 86.

Jaime, J. A. (2016). Formulaciones en el Análisis Envolvente de Datos (DEA). Resolución de casos prácticos. Retrieved from https://idus.us.es/xmlui/bitstream/handle/11441/43744/AlbertoJaime,JaimeTFG.pdf?sequence=1

Lai, P.-L. (2013). A Study on the Relationship Between Airport Privatisation and Airport Efficiency (Issue April). Cardiff University.

Ley de Mercado de Valores. (2011). Testimony of Congreso de la República del Perú.

Margaretha, F., \& Supartika, N. (2016). Factors Affecting Profitability of Small Medium Enterprises (SMEs) Firm Listed in Indonesia Stock Exchange. Journal of Economics, Business and Management, 4(2), 132-137. https://doi.org/10.7763/joebm.2016.v4.379

Masri, M. D., \& Asbu, E. Z. (2018). Productivity change of national health systems in the WHO Eastern Mediterranean region: application of DEA-based Malmquist productivity index. Global Health Research and Policy, 3(1), 1-13. https://doi.org/10.1186/s41256-018-0077-8

Ministerio de Energia y Minas. (2018). Anuario Minero 2018. https://doi.org/10.30875/ee10314e-es

Ministerio de Energia y Minas. (2019). Boletín estadístico minero (Issue 31 May). Retrieved from http://www.minem.gob.pe/minem/archivos/file/Mineria/PUBLICACIONES/VARIABLES/2019/BEMABR2019 .pdf

Mohammadi, A., \& Ranaei, H. (2011). The application of DEA based malmquist productivity index in organizational performance analysis. International Research Journal of Finance and Economics, 62, 68-76.

Muminović, S., \& Barać, Ž. A. (2015). Utječe li produktivnost na profitabilnost poduzeća u industriji prerade mlijeka? $\begin{array}{lllll}\text { Iskustva Slovenije, Hrvatske i } & \text { 269-279. }\end{array}$ https://doi.org/10.15567/mljekarstvo.2015.0407

Olivos, M. (2010). Fundamentos constitucionales de la economía social de mercado en la economía peruana. Revista de Investigación Jurídica, 2, 27.

Périco, A. E., Santana, N. B., \& Do Nascimento Rebelatto, D. A. (2017). Efficiency of Brazilian international airports: Applying the bootstrap data envelopment analysis. Gestao e Producao, 24(2), 370-381. https://doi.org/10.1590/0104-530X1810-15

PwC. (2019). Mine 2019 Resourcing the future.

Rivadeneira, J. (2009). Economía social de mercado - Sosteniblepedia. In 6 De Octubre. Retrieved from http://www.sosteniblepedia.org/index.php?title=Economía_social_de_mercado

Sharif, O., Hasan, M. Z., Kurniasari, F., Hermawan, A., \& Gunardi, A. (2019). Productivity and efficiency analysis using DEA: Evidence from financial companies listed in bursa Malaysia. Management Science Letters, 9(2), 301-312. https://doi.org/10.5267/j.msl.2018.11.010

Sherman, E. (2015). A Manager's Guide to Financial Analysis (6th ed.). American Management Association.

Sociedad Nacional de Minería Petróleo y Energía. (2011). La tributación minera en el Perú: Contribución, carga tributaria y fundamentos conceptuales (First). Aleph.

Vargas, J. J., Olivar, G., \& Cepeda-Cuervo, E. (2016). Malmquist Histórico y de Pronóstico con Series de Tiempo como Modelo Temporal de Análisis Envolvente de Datos. Informacion Tecnologica, 27(3), 141-150. https://doi.org/10.4067/S0718-07642016000300013 
Wang, C. N., Lin, H. S., Hsu, H. P., Le, V. T., \& Lin, T. F. (2016). Applying data envelopment analysis and grey model for the productivity evaluation of Vietnamese agroforestry industry. Sustainability (Switzerland), 8, 1-15. https://doi.org/10.3390/su8111139

Yang, Z., \& Fang, H. (2020). Research on green productivity of chinese real estate companies-based on SBM-DEA and TOBIT models. Sustainability (Switzerland), 12(8). https://doi.org/10.3390/SU12083122

Yi, Y., Ma, F., Huang, D., \& Zhang, Y. (2019). Interest rate level and stock return predictability. Review of Financial Economics, 37(4), 506-522. https://doi.org/10.1002/rfe.1059

Yonnedi, E., \& Rahman Panjaitan, A. (2019). Efficiency and Productivity Analysis of Indonesian Regional Development Banks: Multi-Stage Dea Approach and Malmquist Productivity Index. Jurnal Bisnis Dan Manajemen, 20(2), 145-174. https://doi.org/10.24198/jbm.v20i2.323

Zhu, N., Shah, W. U. H., Kamal, M. A., \& Yasmeen, R. (2020, August). Efficiency and productivity analysis of Pakistan's banking industry: A DEA approach. International Journal of Finance and Economics. https://doi.org/10.1002/ijfe.2123

Zofio, J. L. (2007). Malmquist productivity index decompositions: A unifying framework. Applied Economics, 39(18), 2371-2387. https://doi.org/10.1080/00036840600606260

\section{Copyrights}

Copyright for this article is retained by the author(s), with first publication rights granted to the journal.

This is an open-access article distributed under the terms and conditions of the Creative Commons Attribution license (http://creativecommons.org/licenses/by/4.0/). 